\title{
ДУХОВНІСТЬ ЯК ПРОБЛЕМА НАЦІОТВОРЕННЯ
}

\section{O.I. Шрамко}

Практична здійсненність омріяного віками духовного оновлення суспільства, одягнувшись спочатку в трояндові, а згодом в помаранчеві шати, як ніколи раніше постала дійсно невідкладним, найактуальнішим завданням національного відродження в країнах пострадянського простору. При цьому можливо вперше в історії проблема формування моральносвітоглядної, аксіологічної культури не лише кожної людини, а й нації в цілому так впевнено і твердо заявила не тільки про свою актуальність, а й про свою першочерговість. Вирішення цієї проблеми безпосередньо залежить від розуміння необхідності повної перебудови ціннісної ієрархії сутнісних пріоритетів життєустрою нації. Напружений пошук нових ціннісних орієнтирів окреслює парадигмальне коло глибинних духовних засад людського буття, що концентрується в глобальній, першорядній проблемі сучасності - проблемі духовності.

Проте слід зазначити, що пошук цей надто ускладнюється в епоху сучасної постмодернізації життєвого світу людини й нації-більш-менш струнка раціональна ієрархізація традиційних смислів та цінностей доби Модерну розмивається дисипативними процесами децентрації, масовізації та інфляції. Як наслідок, на перший план виходить проблема бездуховності, яка пов'язується з ціннісною дезорієнтацією, дегуманізацією людини і суспільства, з моральним та релігійним хаосом. Більше того, криза духовності ототожнюється сьогодні не лише з окремими формами культурної реальності, а й з глобальною кризою культури як іманентної форми людського буття.

Актуальність наукового дослідження концепту духовності в контексті реалій сьогодення підкреслюється і тим незаперечним фактом, що феномен духовності безперервно виявляе свою багатомірність, суперечливість, неоднозначну й водночас надзвичайно продуктивну смислову наповненість, а це, в свою чергу, зумовлюе багатоаспектність і принципову 
незавершеність, світоглядну й методологічну відкритість його розгляду.

Таку відкритість на терені сучасної філософії демонструє багатобарвна поліфонія підходів до осмислення проблеми духовності, до розгляду її різноманітних аспектів. Найцікавіші з вітчизняних теоретичних конструктів представлені тут дослідженнями С.В. Пролєєва (онтологічне обгрунтування форм існування духовності та філософсько-категоріального статусу поняття «духовність»), В. Іванова, Г.І. Горак, С.Б. Кримського, В.Г. Табачковського (історико-філософські, соціокультурні, морально-світоглядні ідентифікації духовності), В.С. Возняка, В.А. Малахова, Н.В. Хамітова, Т.А. Хорольської (екзистенційні розвідки смислового поля духовності), В.С. Пісникова, М.М. Холіна (аксіологічні, семантичні та атрибутивні аспекти духовності), I.В. Степаненко (спроба експлікації та концептуалізації інтерсуб'єктивного виміру духовності на постметафізичних засадах), О.І. Зеліченко, О.В.Киричук, Ж.Б. Юзвак (аксіологічний та психолого-педагогічний аналіз духовності), Н.В. Караульної (соціокультурні та структурно-функціональні репрезентації духовності) та ін.

Між тим, аналіз представлених теоретичних побудов дозволяє говорити не лише про суттєві досягнення у вітчизняному осмисленні проблеми духовності, в намаганні охопити різні її грані, але й про певні пробіли, що стосуються деяких важливих її аспектів. Серед останніх - осмислення духовності в контексті націотворчого руху.

Не можна сказати, що цей аспект дослідження духовності зовсім не знайшов освітлення в сучасній вітчизняній філософії. Починаючи з 90-х років ХХ століття вона суттєво поповнюється роботами, в тому числі й дисертаційними, що спрямовані на вивчення різних виявів національного духу - національної ідеї, національної ментальності та національного характеру, національної свідомості й самосвідомості, національної культури тощо. Всі ці дослідження певною мірою торкаються і проблеми духовності, і проблеми становлення нації, але комплексно й цілеспрямовано духовність як проблема націотворення ще не розглядалася. Тому метою даної статті стала спроба накреслити основні орієнтири дослідження цієї проблеми - iï актуальність, методологічні інтенції, константні поняття та історико-філософські джерела.

Серед останніх - філософська, культурфілософська, суспільно-громадська, літературно-мистецька та релігійна спадщина видатних представників української гуманістики, яка надихала не одне покоління поборників національного відродження України і безпосередньо стосується означених аспектів проблеми духовності-творчі доробки М. Максимовича, М. Костомарова, П. Куліша, Т. Шевченка, М. Драгоманова, М. Грушевського, І.Франка, О. Потебні, В. Винниченка, М.Хвильового, Д. Донцова, Д. Чижевського, В. Липинського та ін.

Щодо актуальності, то для сьогоденної України важливість наукового 
дослідження духовності як проблеми націотворення важко переоцінити «помаранчевий» сплеск національного духу чітко визначив пріоритетні виміри сучасного державо- й націотворення. Романтичні революційні гасла дуже швидко переросли в філософськи забарвлені програмно-урядові і окреслили найсуттєвіші складові поняття духовності-справедливість та віру, честь та гідність, відповідальність, духовне єднання, патріотизм, жертовність в ім'я Батьківщини, відновлення втрачених національних та державницьких святинь, відданість роду та заповітам пращурів, національну ідентичність духовної культури, національну самоідентифікацію особистості (належність до українства), толерантність, милосердя, самоповагу та повагу до Іншого.

Ряд цей, безумовно, не може бути обмеженим, недоцільним є й саме завдання повної констатації складових духовності як феномену багатоаспектного, відкритого й принципово невичерпного. Мова йде, передусім, про комплексність підходу до формування певних принципів, а можливо й законів, дотримання яких дозволило б назвати українську націю і українську людину духовно зрілими суб'єктами культурно-історичного процесу, здатними до повноцінного життя, до активної реалізації свого творчого потенціалу, багатого, а головне, унікального досвіду.

Якщо звернутися до сучасних наукових дефініцій духовності, то перераховані вище її складові повною мірою відповідають найавторитетнішим з них - розумінню духовності як «безупинної турботи людини про себе й водночас турботи про світ», як «найвищого рівня ієрархії цінностей людського світовідношення» (В.Г. Табачковський), як «здатності переводити універсум зовнішнього буття у внутрішній всесвіт особистості на етичній основі» (С.Б.Кримський), як «специфічно людської здатності до самовизначення, самотворчості, самотрансцендування до Іншого» або «надутилітарно ціннісного змісту і спрямованості людської життєдіяльності» (I.В. Степаненко) тощо.

Проте сучасний контекст гуманітарного пізнання в Україні вимагає не лише екзистенційно-особистісної і універсально-світоглядної визначеності духовності, а й її національно-ціннісної специфікації. Якщо ж розглядати духовність в контексті програми націотворення, то вона може бути визначена як історично сформований, смислоутворюючий, ціннісноінтенціональний екзистенціал, що забезпечує і спрямовує процес самовідродження, саморозвитку, самореалізації та самозбереження нації в умовах як зовнішньої, так і внутрішньої детермінації соціокультурної динаміки.

Націотворча концептуалізація духовності вимагає інтегративної, метарефлексивної методології, яка здатна охопити і синтезувати спектральномодальні диференціації засобів та методів дослідження визначеної проблеми. Така метарефлексійна інтеграція буде діяти завдяки плюралістичній плідності й ефективності різних методологічних інтенцій - аксіологі- 
чної, екзистенціальної, герменевтичної, феноменологічної, синергетичної, комунікативної, акмеологічної.

Автор не виключає, що перелік цей може бути розширений, звужений або дещо змінений в залежності від тих задач, які ставить перед собою той чи інший дослідник. Проте, на думку автора, будь-яка обрана методологічна платформа, враховуючи недостатню вивченість зазначеної проблеми в сучасному науково-гуманітарному пізнанні, потребує поетапної кореляції її смислового навантаження через низку понять, плідна розробка яких вітчизняними і зарубіжними філософами дозволяє обрати їх в якості константних. Найпершими з них є поняття національного духу, національної ідеї та національної культури.

Наріжне значення названих понять для дослідження духовності як проблеми націотворення повною мірою підтверджує і звернення до історико-філософських експлікацій націотворчих аспектів духовності. Спробуємо прослідкувати це на прикладі вітчизняної філософської думки, історія якої невідривно пов'язана не лише з історією професійної філософської теорії, а й з історією філософські спрямованої суспільної й політичної, наукової і релігійної, літературної і художньої діяльності видатних речників української культури.

Проблему національного у вітчизняному гуманітарному просторі вперше яскраво висвітлила романтична хвиля осмислення дійсності, коли в українській філософії виникають питання, що стосуються національного духу і національної самосвідомості, національної самоідентифікації особистості і культурної самоідентифікації нації. Виникнення цих питань започатковує в Україні традицію філософської рефлексії національної ідеї як форми усвідомлення своєї причетності до національної спільноти і усвідомлення власної нації як суб'єкта всесвітньо-історичного процесу розвитку культури. Відтепер вітчизняна філософія стає сферою реалізації потреби пізнання духу народу, сферою усвідомлення найвищих духовних потреб української людини і української нації, а філософське осмислення національної ідеї - духовним джерелом самовідродження нації.

Вже на ранньому етапі свого розвитку, окресленого творчістю Кирило-Мефодіївського товариства, філософія української національної ідеї спрямувала проблематику духовності в русло роздумів над відродженням національної самосвідомості, створенням культурного образу України, усвідомленням національної специфіки українського народу, його національного духу. Значною мірою цьому сприяла романтична забарвленість київського періоду творчості Михайла Максимовича, який намагався виявити цю специфіку, виявити «емблеми духу» українського народу, які визначають, як він вважав, особливості національного характеру.

Ці думки були підхоплені одним із засновників Кирило-Мефодіївського товариства - Миколою Костомаровим, який вимальовує свій погляд на 
Україну та її місце в світі через ствердження самості українського народу, неповторності рис, що визначають його характер і мову. Костомаров підкреслював, що грунтом дослідження української історії та культури має стати пізнання першоджерел культурно-історичного розвитку націїiï «народного духу», що визначає неповторне національне обличчя. Це твердження Костомарова має цілком романтичне коріння - насамперед, німецьке, адже ніхто так впевнено як німецькі романтики (слідом за Гердером, Фіхте й Гегелем) не стверджував, що культура й історія $\epsilon$ виявом людського духу, а німецька культура - виявом німецького духу.

Романтично забарвлена і проблематика духовності в концепції національної культури, створеній Пантелеймоном Кулішем, який усе своє життя присвятив ідеї України і проблемі формування національної самосвідомості українського народу. Його думки про провідну роль культурної діяльності у пробудженні вічних культурних цінностей і традицій, які формують душу народу; про рідну мову як єдиний виразник найсокровенніших рухів цієї душі; про хутір як осередок української культури і українського народного духу; про перевагу жіночого - кордоцентричного, душевного начала української культури несуть у собі те ж саме романтичне прагнення пізнати «дух народу» і пробудити його до самостійного й вільного життя.

Пробудженню національної свідомості, ідеї духовного переображення України присвятив більшу частину свого творчого наробітку і Тарас Шевченко. У створеному ним образі України, що ввібрав у себе світ унікального буття людської особистості, дух українського народу розкривається на екзистенційному, неповторно-самобутньому рівні культурного й національного самотворення. «Володарем у царстві духа» назвав Шевченка Іван Франко, а Оксана Забужко ставить його в один ряд письменників творців національно-консолідуючого авторського міфа, від Данте й Сервантеса до Гете [3, с.18]. Це означає, що для формування української національної свідомості та становлення української нації феномен Шевченка («Шевченків міф України») став такою ж націотворчою силою, як Данте для Італії, Сервантес для Іспанії, а Гете для Німеччини. Більше того, за словами Забужко, і сьогодні Шевченків міф - «головний духовний набуток України загальноцивілізаційного значення» [3, с. 159].

Духовну спорідненість з кириломефодіївцями виявили в осмисленні шляхів націотворчого розвитку України і найвизначніші представники так званого «громадівського» руху - Олександр Потебня та Михайло Драгоманов. У творчості цих мислителів також простежується зв'язок з романтичною традицією звернення до проблеми пізнання народного духу, «духу нації», з увагою до національної неповторності культурного буття. У Потебні- через розвиток ідей Вільгельма Гумбольдта про тотожність мови 3 духом нації, через осмислення поняття націоналізму та «ідеї на- 
ціональності», а у Драгоманова - не тільки через романтичний підхід до виявлення специфіки національного духу шляхом фольклорних та етнографічних досліджень раннього етапу діяльності, але й через концепцію національного самопізнання й національної самосвідомості, що була висунута Драгомановим-позитивістом. На його думку, без усвідомлення свого місця в системі загальнокультурних, міжнаціональних відносин жодна нація не здатна ствердити своє право на самостійний розвиток.

Звернення до проблеми національної самосвідомості як центральної у філософському осмисленні національної ідеї характерне і для представників «Молодої України». В творчості її лідера, Івана Франка духовні аспекти націотворення знайшли своє концентроване вираження. Стрижньову ідею власного філософського пошуку - ідею героя, проведену темою «особистість і народ» - «індивід і нація»-«будитель і народ», Франко розкриває за допомогою основного лейтмотиву своєї націотворчої діяльності - думки про перетворення українського етносу на націю, а кожної української людини на її самостійний компонент. За Франком, залучення до нації як органічної складової культурно-історичного процесу є обов'язковою передумовою становлення людської особистості, а національне«потребою душі», іманентним проявом індивідуального духу.

Початок ХХ століття дає Україні нову плеяду громадських і культурних діячів, які продовжують справу своїх попередників і звертаються до філософського осмислення проблеми духовності з позицій «української національної ідеї». Їх зусилля вже мали цілком реальний результатстворення Української незалежної держави i, не дивлячись на те, що держава ця проіснувала недовго, духовні здобутки її натхненників значно вплинули на всю подальшу історію націо- й державотворення в Україні.

Найпершим тут слід назвати ім'я Михайла Грушевського - його роздуми над «всіма усвідомленими елементами нашого громадянства» найтісніше пов'язують практичні кроки на ниві національного державотворення $з$ питаннями духовного становлення нації. Розроблена Грушевським концепція культурно-історичного поступу, суб'єктом якого є народ, вказує на фундаментальні засади формування «самопочуття нації»-це національне самопізнання й самовизначення: «...для народу, який вступає на новий шлях, перше діло, - вважає Грушевський, - „випростуватись“... Сей процес національного випростовування, розпочатий самими зверхніми реальними умовами, твердими, аж занадто, подіями, мусить бути свідомо продовжений всіма усвідомленими елементами нашого громадянства, щоб знайти „свою долю і свій шлях широкий“ в сучасних обставинах». А для цього, - продовжує Грушевський, - «...ми мусимо „пізнати себе“, і пізнавши раз, держатись твердо тої лінії, яку вказує нам се пізнаннє...» $[1$, с. $51-52]$.

Заслуговує на увагу і підхід до філософського осмислення проблеми 
національного і духовного відомого українського правознавця та соціолога Богдана Кістяківського, який багато уваги приділяє розробці категорії національної культури, розглядаючи іï «як вираз душі народу».

З початком процесу українізації, що розвернувся в Україні у 20-ті роки, проблематика духовності активізується і зосереджується на дослідженнях в галузі філософського осмислення національної культури і зусиллях по розробці філософії української ідеї. Поштовхом такої активізації стає програма вирішення дилеми «двох культур», висунута ідеологом українізації Миколою Скрипником. Як відомо, всупереч перспективі витіснення української культури російською, Скрипник пропонує, навпаки, приділити національній культурі найпильнішу увагу і навчитись володіти цією культурою, що допоможе, як він вважав, краще порозумітися зі своїм народом і пізнати його.

Це ж питання постає і в центрі культурологічної концепції «азіатського ренесансу» Миколи Хвильового, для якого також неприйнятним $\epsilon$ надмірне піднесення російської культури. Орієнтація ж «на грандіозні досягнення Європи», пропонована ним, ні в якому разі не принижує ролі національної культури і загалом ролі України в культурно-історичному процесі розвитку людства. Навпроти, саме Україні призначено «нести світло з Азії», стати «оазисом азіатського ренесансу», бо для цього $\epsilon$ всі підстави і підстави ці визначаються, насамперед, палким бажанням національного самовизначення і наявністю вихованого українською культурою типу сильного духом «борця-конкістадора». (Важко не співставити ідеї Хвильового з сьогоденними подіями в Україні-чи не цей дух нарешті прокинувся, щоб стати по-справжньому всенародним?)

Концепція Хвильового викликала досить активну дискусію, впродовж якої було висловлено чимало плідних думок, що могли б спричинитися до подальшого прогресу щодо філософського осмислення духовності. Але, як відомо, цього не сталося. Мрії Хвильового та його однодумців про відродження української нації та української культури перетворилися на «розстріляне відродження». Проте розвиток націотворчих аспектів проблеми духовності на цьому не припиняється, а активно продовжується в дослідженнях діячів української діаспори.

Серед цих досліджень найпильнішої уваги заслуговують теорія інтегрального націоналізму і концепція волі до рідної культури Дмитра Донцова, розробка категорії «нація» та концепція духовних засад творення української держави В'ячеслава Липинського, осмислення культури в філософській концепції українознавства Дмитра Чижевського і багато інших значних доробків представників української діаспори. Ми ж обмежимося тут менш відомими на сьогоднішній день наробітками українських мислителів, що працювали за межами України.

У цьому плані привертає увагу робота Б. Романенчука «Що творить 
націю», у якій розглядається проблема основних чинників націотворення. Звертаючись до історії проблеми, Романенчук простежує різні її аспекти, зупиняючись на осмисленні ролі, яку відіграють у процесі становлення нації культура, дух, мова, свідомість тощо. Цікаво, що чи не найбільше при цьому автора хвилює такий чинник націотворення як культура. Починаючи від однієї з найперших теорій походження нації - теорії Гердера, «яка розглядає культуру як головний чинник, який з певної групи людей творить націю» [4, с. 765], Романенчук наголошує на думці Гердера про те, що культура $\epsilon$ вираженням внутрішньої свідомості народу і завдяки культурі «кожна національна одиниця визнає себе інтегральною частиною суспільно-національної цілості. Посідання такої спільної культури, підкреслює автор, - Гердер називав національністю - фольк-народом» $[4$, c. 767].

Важливими видаються і згадувані Романенчуком ідеї Гердера про співвідношення національного духу або душі народу і культури. За Гердером, національна душа об'єднує національну групу i «є генетичною силою і матір'ю всіх культур на землі, і навпаки, всі культури є експресією національної душі» [4, с.767]. Під впливом ідей Гердера наголошує на національних підставах культури і культурних основах німецької нації й Фіхте [4, с. 769]. До «культурників» відносить Романенчук і Гегеля, який зазначив, що «без культури нема нації, як і нації-без культури. Культурне життя нації є атмосферою, в якій пробуджується дух нації і вище розвивається культура, яка є серцем національного організму» [4, с. 770].

I все ж, віддавши належне високій оцінці культури як основного чинника націотворення в теоретичній спадщині німецьких мислителів, Романенчук робить протилежні висновки: «Шо ж до культури, - пише він, у висновку треба сказати, що яка б не була висока культура народу, вона не $\epsilon$ головним націотворчим чинником, хоч певну участь у творенні нації вона, без сумніву, має...» [4, с.772]. Далі він підтверджує свій висновок і зверненням до книжки «Теорія нації» (Відень, 1922) професора Львівського таємного університету Володимира Старосольського, який вважав, що «не культура творить націю, а тільки нація творить культуру» $[4$, c. 779$]$.

Як на нашу думку, із запереченням осмислення культури як головного чинника націотворення можна погодитись лише у тому випадку, якщо розглядати її однобічно і забути про давно вже усталений європейський концепт культури як буття духу, а також про майже двохсотлітню філософську традицію «ототожнення нації з усією ㄲï духовною культурою в цілому, як ідеальною іпостассю цієї нації» [2, с.30], на якій грунтується сучасне розуміння нації не як природної, а духовної засади. Якщо ж розуміти культуру як буття духу, то вона постає не просто дієвим чинником творення нації, а отримує значно ширші повноваження - повноваження 
інституту націотворення [5, с. 267-268].

Осмислення культури як духу нації уможливлює і усвідомлення національної ідеї як ідеї культури, проте такий ракурс філософської рефлексії національної ідеї потребує окремого дослідження. Але можна впевнено говорити про те, що процес становлення нації, який спирається на ствердження національної ідеї, «вимірюється» насамперед мірою культурного національного й особистісного самовизначення. I саме духовність як найвищий рівень ціннісно-ієрархічної будови культури репрезентує сьогодні національну ідею України, яка забезпечує і спрямовує процес самовідродження та самореалізації нації.

У підсумку слід зазначити, що лише поверхневий екскурс в історію вітчизняної філософської думки підтверджує не тільки суттєве значення, а й взаємопов'язаність понять національного духу, національної ідеї та національної культури у смисловому полі дослідження духовності як проблеми націотворення. Такий висновок потребує і більш розширеної історичної та сучасної філософської експлікації зазначених понять, і їхньої більш конкретної смислової кореляції відносно досліджуваної проблеми, подальші розвідки якої автор буде намагатися спрямувати саме в це русло.

\section{1 Бібліографія}

[1] Грушевсъкий M. На порозі Нової України: Гадки і мрії. - К.: Наукова думка, 1991.

[2] Забужско О. Філософія української ідеї та європейський контекст: франківський період. - К.: Основи, 1993.

[3] Забужко О. Шевченків міф України. Спроба філософського аналізу. - Вид. друге, випр. - К.: Факт, 2001.

[4] Романенчук Б. Що творить націю // Хроніка - 2000: Український культурологічний альманах. - Київ: Центр практичної філософії, 2000.- Вип. 39-40.- С. 760-795.

[5] Шрамко O.I. Феномен культури у соціальному просторі становлення нації // Актуальні проблеми духовності. - Вип. 4 (1). - Кривий Ріг: Видавництво «I.В.I.», 2002. - С. 264-269. 